\title{
Myb-Related Protein A
}

National Cancer Institute

\section{Source}

National Cancer Institute. Myb-Related Protein A. NCI Thesaurus. Code C17810.

Myb-related protein A (752 aa, $\sim 86 \mathrm{kDa}$ ) is encoded by the human MYBL1 gene. This protein plays a role in transcriptional regulation. 